\title{
Pengembangan Kompetensi Penyuluh Pertanian Berbasis Media Massa
}

\author{
Oos M. Anwas \\ Peneliti Madya di Pustekkom Kemdiknas, e-mail: anwasipb@yahoo.co.id
}

\begin{abstract}
Abstrak: Penelitian ini bertujuan untuk menganalisis intensitas pemanfaatan media massa, kesesuaian substansi media massa dengan kebutuhan penyuluhan, dan pengaruhnya terhadap kompetensi penyuluh pertanian. Media massa yang dimaksudkan adalah koran, majalah, buku, radio, televisi, dan internet. Penelitian ini dilakukan dengan metode survai terhadap penyuluh pertanian PNS padi di kabupaten Karawang dan penyuluh sayuran di kabupaten Garut Provinsi Jawa Barat. Sampel diambil secara random sebanyak 170 orang. Hasil analisis deskriptif diketahui secara umum intensitas pemanfaatan media massa adalah rendah. Secara khusus intensitas pemanfaatan media: koran, buku, radio, dan internet dalam kategori sangat rendah. Pemanfaatan majalah dalam kategori sedang, dan hanya intensitas pemanfaatan media televisi dalam kategori tinggi walaupun substansinya kurang sesuai dengan kebutuhan penyuluhan. Melalui analisis regresi berganda diketahui bahwa media massa yang berpengaruh terhadap kompetensi penyuluh adalah majalah yang substansinya sesuai dengan kebutuhan penyuluhan, mudah diakses, dan dilakukan secara kontinyu. Di sisi lain, intensitas pemanfaatan media televisi yang tinggi memiliki potensi sebagai media yang dapat digunakan untuk peningkatan kompetensi penyuluh.
\end{abstract}

Kata kunci: media massa dan kompetensi penyuluh pertanian

\begin{abstract}
This study aimed is to analyze the intensity of the use of mass media, the suitability of the substance of the mass media with the needs of extension education, and their effects on the competency of agricultural extension agents. The mass media mentioned in this study were newspapers, magazines, books, radio, television and the internet. This research was conducted by survey method on the paddy extension agent PNS within districts of Karawang and the vegetable extension agent government employee in the district of Garut, West Java. Samples were randomly taken as much as 170 people. The result of descriptive analysis showed that the intensity of mass media utilization was low. The intensity of particular mass media utilization especially newspapers, books, radio and the internet were in a very low category. Utilization of the magazine was in fair category. Only the intensity of television media utilization was in the high category, even though their substances were less in accordance with the needs of the extension education. The multiple regression analysis found that the mass media that influence the competency of agricultural extension agents was the magazine by which the substance was in accordance with the needs of extension education, accessible, and continuous. On the other hand the high intensity of television media utilization was potential to increase the competency of agricultural extension agents.
\end{abstract}

Key words: mass media and competency of agricultural extension agents.

\section{Pendahuluan}

Ilmu pengetahuan dan teknologi berkembang cepat seiring tuntutan perubahan zaman. Perkembangan teknologi informasi dan komunikasi terutama sejak munculnya teknologi internet telah menyebabkan perubahan besar dalam masyarakat. Produk teknologi informasi yang relatif murah dan terjangkau memudahkan akses informasi melampaui batas negara dan batas kultur/budaya. Kondisi ini telah merambah ke semua lapisan kehidupan manusia termasuk para petani di pedesaan. Kini sebagian petani sudah terbiasa mengakses informasi melalui koran, majalah, radio, televisi, internet, handphone, atau media lainnya.

Seiring perubahan zaman tersebut, masalah pertanian yang dihadapi para petani juga semakin kompleks. Masalah tersebut dimulai dari meningkatkan jumlah dan mutu produksi serta pemasaran, hingga akses informasi petani yang 
terus berkembang. Kompetisi produk pertanian tidak hanya dalam tataran lokal akan tetapi berubah menjadi global. Para petani dituntut untuk bisa menyesuaikan dengan perkembangan zaman, sehingga petani yang bisa mengikuti perkembangan zaman akan eksis. Sebaliknya, petani yang tidak bisa menyesuaikan dengan perubahan semakin terpinggirkan. Oleh karena itu, peran penyuluh menjadi penting sebagai fasilitator dalam mengembangkan potensi petani. Sebagai konsekuensinya penyuluh dituntut untuk mampu menyesuaikan dengan perubahan dan tuntutan masyarakat melalui proses belajar.

Tuntutan profesionalisme idealnya ditunjang oleh tenaga penyuluh yang profesional, namun menurut Slamet (2008) tenaga-tenaga penyuluh yang profesional sesuai dengan tuntutan lapangan belum cukup tersedia. Kondisi ini mengindikasikan perlunya berbagai pihak untuk mengkaji bagaimana meningkatkan kualitas penyuluh.

Di era informasi ini banyak media yang dapat dimanfaatkan (by utilization) untuk meningkatkan kemampuan penyuluh. Media tersebut khususnya adalah media massa yang cenderung dinamis dan berkembang seiring perubahan yang terjadi di masyarakat. Kelebihan lain, media massa dapat dimanfaatkan secara fleksibel di mana atau kapan pun setiap ada kesempatan. Melalui pemanfaatan media tersebut, penyuluh dapat belajar mengimbangi perubahan yang terjadi dalam masyarakat. Oleh karena itu, menarik untuk dilakukan penelitian tentang bagaimana intensitas pemanfaatan media massa dan media massa apa yang memiliki pengaruh signifikan terhadap peningkatan kompetensi penyuluh pertanian. Secara lebih rinci, penelitian ini bertujuan untuk menganalisis intensitas pemanfaatan media massa dalam peningkatan kompetensi penyuluh, menganalisis kesesuaian substansi media massa dengan kebutuhan penyuluhan, dan menganalisis media massa yang berpengaruh dalam peningkatan kompetensi penyuluh.

\section{Kajian Pustaka}

Konsep media massa terkait dengan komunikasi massa. Sejarah lahirnya komunikasi massa bersamaan dengan lahirnya alat-alat mekanik yang mampu melipatgandakan pesan-pesan komunikasi yaitu sejak ditemukannya mesin cetak oleh J. Guetenberg (Wiryanto, 2000). Alat-alat mekanik tersebut sebagian besar disebut media massa.

Komunikasi massa seringkali identik dengan audien yang relatif besar dan heterogen (Wright, dalam Severin dan Tankard, 2001). Karena itu, media massa merupakan media komunikasi publik yang sasarannya besar, pesannya bersifat umum dan heterogen. Seiring perkembangan teknologi informasi dan komunikasi, konsep komunikasi massa mengalami pergeseran. Realitas tersebut telah disadari industri media massa (surat kabar, majalah, buku, radio, televisi, radio, dan internet), sehingga saat ini sasarannya sudah cenderung spesifik (segmented).

Harold Lasswell, mengemukakan model komunikasi yang sederhana dan sering dikutip banyak orang yakni Siapa (who), berbicara apa (says what), dalam saluran yang mana (in which channel), kepada siapa (to whom, dan pengaruh seperti apa (what that effect) (Littlejhon, 1996). Teori-teori efek komunikasi massa, Lazarsfeld dengan teori komunikasi dua tahap (two step flow) dan konsep 'pemuka pendapat'. Teori ini sejalan dengan Kincaid dan Schramm (1987), bahwa penerusan arus informasi media massa yang terjadi tidak hanya dua tahap tersebut, tetapi tiga tahap, bahkan melewati beberapa tahap yang panjang. Teori spiral keheningan (the spiral of silence) dari Elizabeth Noelle-Neuman, menjelaskan bahwa terbentuknya pendapat umum ditentukan oleh suatu proses saling mempengaruhi antara komunikasi massa, komunikasi antarpribadi, dan persepsi individu tentang pendapatnya dalam hubungannya dengan pendapat orang-orang lain sekitarnya (dalam Severin dan Tankard, 2001).

Media massa menurut teori agenda-setting dari McCombs dan DL Shaw (Sendjaja dan Sumawinardi, 1994) memiliki pengaruh dan penekanan informasi tertentu terhadap masyarakat. Namun, teori ini diimbangi oleh teori Uses and Gratifications dari Katz (Severin dan Tankard, 2001), bahwa pengguna (uses) media atau khalayak adalah aktif dan selektif dalam menggunakan media untuk memenuhi kebutuhan dan kepentingannya.

Dalam kontek pembangunan, media massa memiliki peran penting. Hasil studi Schramm 
(Nasution, 2007) peran paling pokok media massa adalah membantu menyebarluaskan informasi tentang pembangunan, dapat mengajar melek huruf, serta keterampilan lainnya yang dibutuhkan untuk pembangunan dan dapat menjadi penyalur suara masyarakat agar turut ambil bagian dalam pembuatan keputusan. Media massa tidak hanya berperan dalam menimbulkan dan memberikan informasi, tetapi lebih jauh dapat mengarahkan untuk tujuan-tujuan penyuluhan dan pembangunan (Oepen, 1988). Dalam perkembangannya terutama munculnya media internet, media juga memiliki fungsi interaktif dalam menciptakan komunitas maya dan budaya maya, membina hubungan sosial, termasuk dalam melakukan transaksi bisnis.

Media massa dalam kaitannya dengan media pembelajaran, setiap individu (penyuluh) dapat melakukan proses belajar melalui media apa pun, sekalipun media tersebut tidak dirancang khusus untuk proses belajar. Misalnya, individu (penyuluh) dapat mengikuti siaran televisi tentang pencegahan Flu Burung. Dengan membaca koran misalnya, penyuluh dapat belajar budidaya tanaman jagung yang berhasil dikembangkan di suatu daerah. Begitu pun dengan media lainnya, penyuluh dapat belajar dengan cara, waktu, dan tempat yang sesuai dengan dirinya. Media seperti: suratkabar, majalah, buku, radio, televisi, dan internet dapat dimanfaatkan oleh siapa pun yang bisa mengaksesnya sebagai media belajar. Oleh karena itu, media massa yang beraneka ragam dan memiliki banyak informasi ini apabila dimanfaatkan dapat meningkatkan kemampuan penyuluh.

Konsep kompetensi mengacu pada pemikiran Boyatzis (1984), Spencer and Spencer (1993), Sumardjo, (2008), yang disarikan bahwa kompetensi adalah kemampuan yang dilandasi oleh pengetahuan, keterampilan, dan didukung oleh sikapnya yang dituntut dalam melaksanakan tugas pekerjaannya. Ini berarti kompetensi penyuluh pertanian adalah kemampuan yang dilandasi oleh pengetahuan, keterampilan, dan didukung oleh sikap yang dituntut dalam melaksanakan tugasnya dalam memberdayakan petani. Penyuluh yang memiliki kompetensi baik adalah penyuluh yang dapat memberdayakan petani atau meningkatkan partisipasi petani seluas-luasnya untuk menjadi subjek dalam usaha pertaniannya.

\section{Metodologi Penelitian}

Penelitian ini menggunakan metode survei. Variabel yang diteliti adalah intensitas pemanfaatan media, seperti koran, majalah, buku, radio, televisi, dan internet sebagai variabel indenpenden, sedangkan kompetensi penyuluh pertanian sebagai variabel indenpenden. Populasi dalam penelitian ini adalah penyuluh pertanian Pegawai Negeri Sipil (PNS) yang bertugas di daerah pertanian padi di kabupaten Karawang dan penyuluh yang bertugas di daerah pertanian sayuran di kabupaten Garut, Provinsi Jawa Barat. Sampel diambil secara random menggunakan teknik random sampling dengan rumus Slovin (Sevilla $d k k$., 1993) pada kelonggaran sebesar 7 persen. Sampel berjumlah 170 orang. Instrumen penelitian sebelumnya telah dilakukan uji validitas dan reliabilitasnya. Pengumpulan data dilakukan pada bulan Februari sampai dengan April 2009. Data yang dikumpulkan menggunakan pengamatan, kuesioner, dan wawancara mendalam (indepth interview). Pengolahan data menggunakan analisis statistik deskriptif dan analisis regresi berganda, dengan aplikasi SPSS versi 14.

\section{Hasil Penelitian dan Bahasan}

Secara umum intensitas pemanfaatan media massa (koran, majalah/tabloid, buku, radio, televisi, dan internet) dalam kategori rendah dengan rataan skor 35 (Tabel 1). Secara khusus pemanfaatan media: koran, buku, radio, dan internet dalam kategori sangat rendah. Pemanfaatan majalah dalam kategori sedang dan hanya intensitas pemanfaatan media televisi dalam kategori tinggi. Di sisi lain substansi media massa tersebut kurang sesuai dengan penyuluhan (Tabel 2).

Secara lebih khusus intensitas pemanfaatan media koran adalah 72 persen responden menyatakan sangat rendah dengan rataan skor 18. Ini menunjukkan bahwa intensitas pemanfaatan media koran secara umum sangat rendah. Substansi informasi yang diperoleh penyuluh dari terpaan (keterdadahan) media koran (Tabel 2) bersifat umum yang kurang sesuai dengan kebutuhan penyuluhan. Informasi tentang pertanian yang dibutuhkan dalam penyuluhan ternyata hanya 25 persen. Ini berarti substansi 
Tabel 1. Sebaran Persentase dan Rataan Skor Pemanfaatan Media Massa

\begin{tabular}{|l|c|c|c|c|c|}
\hline \multirow{2}{*}{$\begin{array}{l}\text { Intensitas } \\
\text { Pemanfaatan }\end{array}$} & \multicolumn{4}{|c|}{ Kategori \% } & Rataan \\
\cline { 2 - 5 } & $\begin{array}{c}\text { Sangat } \\
\text { Rendah }\end{array}$ & Rendah & Sedang & Tinggi & \\
\hline Koran & 72 & 18 & 7 & 3 & 18 \\
Majalah & 33 & 38 & 7 & 22 & 54 \\
Buku & 74 & 11 & 12 & 4 & 24 \\
Radio & 75 & 21 & 3 & 1 & 17 \\
Televisi & 5 & 3 & 11 & 81 & 89 \\
Internet & 82 & 11 & 7 & 1 & 8 \\
\hline
\end{tabular}

Keterangan: $0-25$ = Sangat rendah, $26-50=$ Rendah, $51-75=$ Sedang, $76-100=$ Tinggi

koran yang sering dibaca oleh penyuluh adalah informasi bersifat umum seperti politik, hiburan, olahraga, ekonomi bisnis, dan informasi lainnya.

Untuk lebih meyakinkan informasi yang diperoleh dari koran, dapat dianalisis dari karakteristik nama koran yang sering dibaca penyuluh (Gambar 1). Koran yang sering dibaca adalah koran lokal tingkat kabupaten, yaitu Radar Garut dan Radar Karawang sebesar 39 persen. Selanjutnya, diikuti oleh koran Pikiran Rakyat sebagai koran lokal tingkat provinsi Jawa Barat mencapai 31 persen. Sebagai koran lokal, selain menyajikan informasi lokal, juga informasi nasional dan juga global dalam persfektif lokal. Koran nasional ada dalam kisaran 10 s.d. 20 persen. Apabila dianalisis lebih mendalam, substansi semua jenis koran yang sering dibaca penyuluh adalah informasi umum (Tabel 2). Informasi yang terkait langsung dengan penyuluhan masih kurang. Terbukti pula masih belum ada koran (harian) yang secara khusus membahas tentang pertanian seperti dalam majalah Sinar Tani.
Intensitas pemanfaatan majalah (Tabel 1) menunjukkan kategori sedang. Majalah Sinar Tani dan Trubus merupakan majalah yang paling sering dibaca penyuluh. Kedua majalah tersebut substansinya secara spesifik merupakan majalah pertanian, sedangkan majalah Tempo dan Gatra informasinya cenderung umum. Majalah Sinar Tani diterbitkan oleh PT Duta Karya Swasta yang bekerja sama dengan Departemen Pertanian. Majalah ini didistribusikan kepada seluruh penyuluh PNS di Indonesia. Oleh karena itu, wajar apabila penyuluh hampir seluruhnya memiliki dan membaca majalah ini. Topik-topik aktual yang terkait dengan pertanian menjadi bahasan utama majalah Sinar Tani. Majalah ini juga menyajikan inovasi atau teknologi baru, kajian permasalahan pertanian, sharing pengalaman, dan juga sebagai media komunikasi.

Hasil pendalaman juga diketahui bahwa melalui majalah ini informasi yang sering dibaca penyuluh (Tabel 2 ) sebagian besar adalah informasi pertanian. Ada tiga jenis informasi

Tabel 2. Sebaran Persentase Informasi yang diperoleh penyuluh dari Media Massa

\begin{tabular}{|l|c|c|c|c|c|c|}
\hline \multirow{2}{*}{$\begin{array}{l}\text { Jenis } \\
\text { Massa }\end{array}$} & \multicolumn{6}{|c|}{ Informasi yang diperoleh dari media } \\
\cline { 2 - 7 } & $\begin{array}{c}\text { Hiburan/ } \\
\text { olahraga }\end{array}$ & Politik & $\begin{array}{c}\text { Ekonomi/ } \\
\text { Bisnis }\end{array}$ & $\begin{array}{c}\text { Pen- } \\
\text { didikan }\end{array}$ & $\begin{array}{c}\text { Perta- } \\
\text { nian }\end{array}$ & $\begin{array}{c}\text { Lain- } \\
\text { lain }\end{array}$ \\
\hline Koran & 22 & 35 & 29 & 32 & 25 & 24 \\
\hline Majalah & 7 & 14 & 75 & 30 & 86 & 11 \\
\hline Buku & 8 & 18 & 55 & 41 & 65 & 4 \\
\hline Radio & 51 & 21 & 41 & 33 & 23 & 4 \\
\hline Televisi & 76 & 61 & 64 & 52 & 43 & 7 \\
\hline Internet & 14 & 0 & 7 & 0 & 2 & 2 \\
\hline
\end{tabular}

Keterangan: $0-25=$ Sangat rendah, $26-50=$ Rendah, $51-75=$ Sedang, $76-100=$ Tinggi 


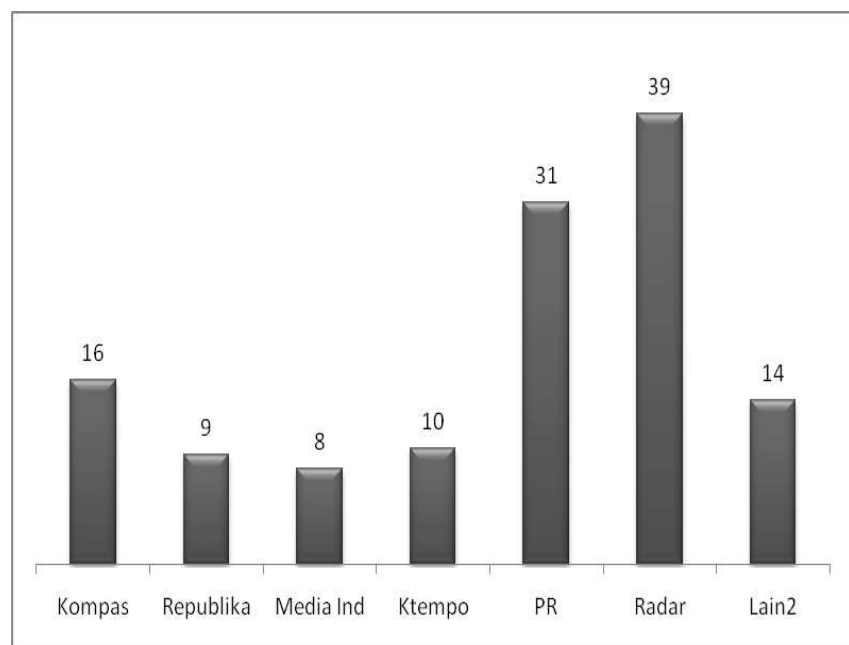

Gambar 1. Nama Koran yang dibaca Penyuluh

tertinggi yang diperoleh penyuluh dari majalah, yaitu informasi pertanian (86 persen), informasi tentang ekonomi dan bisnis (75 persen), dan informasi yang terkait dengan pendidikan (30 persen). Ketiga jenis informasi tersebut sangat dibutuhkan untuk kegiatan penyuluhan pertanian.

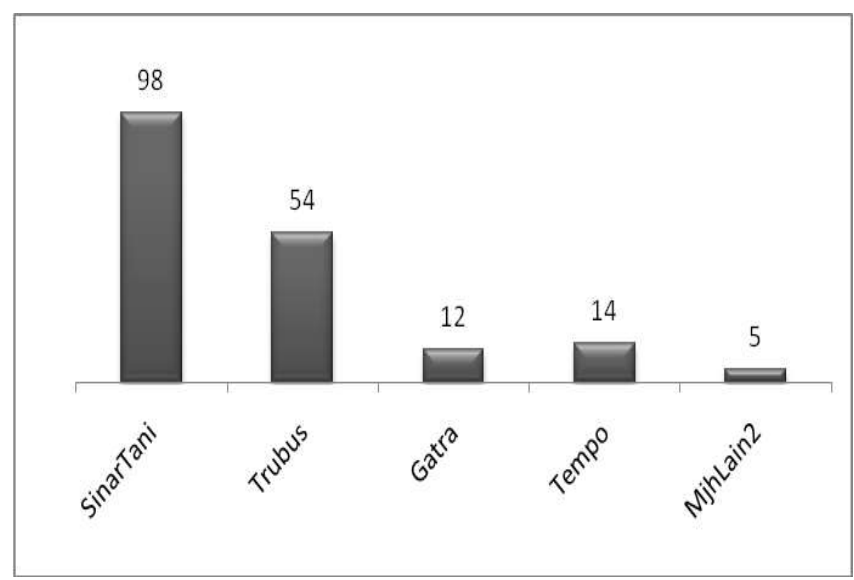

Gambar 2. Nama Majalah yang dibaca Penyuluh

Uraian data pendukung tersebut menunjukkan bahwa karakteristik majalah yang sering dibaca penyuluh adalah (1) majalah yang spesifik tentang pertanian; (2) substansi yang diperoleh juga terkait dengan pertanian dan keperluan kegiatan penyuluhan, serta (3) majalah tersebut (khususnya Sinar Tani) diperoleh secara kontinyu (dua kali dalam sebulan).

Intensitas pemanfaatan buku secara umum menunjukkan kategori sangat rendah dengan rataan skor 24. Ini menunjukkan bahwa pemanfaatan buku yang dilakukan penyuluh sebagai proses belajar baik di daerah pertanian padi ataupun pertanian sayuran adalah sangat rendah. Rendahnya membaca buku ini terkait dengan isi buku yang kalah menarik daripada majalah. Isi majalah lebih up to date, sesuai dengan perkembangan, sehingga lebih menarik untuk dibaca. Di sisi lain, secara umum budaya baca bangsa Indonesia masih rendah termasuk kaum terdidik seperti penyuluh ini. Adapun jenis buku yang sering dibaca penyuluh (Tabel 2 ) sebagian besar tentang pertanian (65 persen), ekonomi dan bisnis ( 55 persen), dan pendidikan (41 persen).

Intensitas pemanfaatan radio juga sangat rendah (Tabel 1). Hal ini ditunjukkan dengan rataan skor hanya 17 . Secara umum di masyarakat, media radio sebagai media elektronik, daya tariknya kurang jika dibandingkan dengan media televisi yang mampu menyajikan pesan audio visual. Hal ini juga terbukti di lingkungan penyuluh, pemanfaatan radio sangat rendah. Materi siaran radio atau acara yang diikuti penyuluh sebagian besar bersifat hiburan (Tabel 2). Data ini didukung pula oleh stasiun radio yang sering didengarkan penyuluh dalam (Gambar 3) sebagian besar adalah radio swasta yang materi siarannya masih kurang relevan dengan kegiatan penyuluhan.

Media radio memiliki kelebihan, di antaranya praktis dibawa ke mana-mana dan dapat dimanfaatkan sambil bekerja di kebun/sawah. Media ini dapat melengkapi kelemahan yang dimiliki media massa lain seperti koran, majalah, TV, dan juga internet. Ini adalah peluang untuk dimanfaatkan, namun materi siaran radio yang terkait dengan pertanian masih sangat kurang, apalagi di Karawang dan Garut belum memiliki stasiun radio yang khusus menyiarkan tentang pertanian. Begitu pula dari aspek rataan skor intensitas pemanfaatan media radio sangat rendah. Artinya, penyuluh secara umum jarang mendengarkan siaran radio dan substansi acara radio lebih banyak unsur hiburan.

Intensitas pemanfaatan media televisi ditunjukkan dengan rataan skor tinggi, yaitu 89, dengan 81 persen responden menyatakan tinggi dalam pemanfaatan media ini (Tabel 1 ). Tingginya intensitas pemanfaatan media televisi ini membuktikan bahwa media televisi menjadi media yang paling digemari oleh masyarakat, termasuk penyuluh. Hanya substansi acara didominasi oleh 


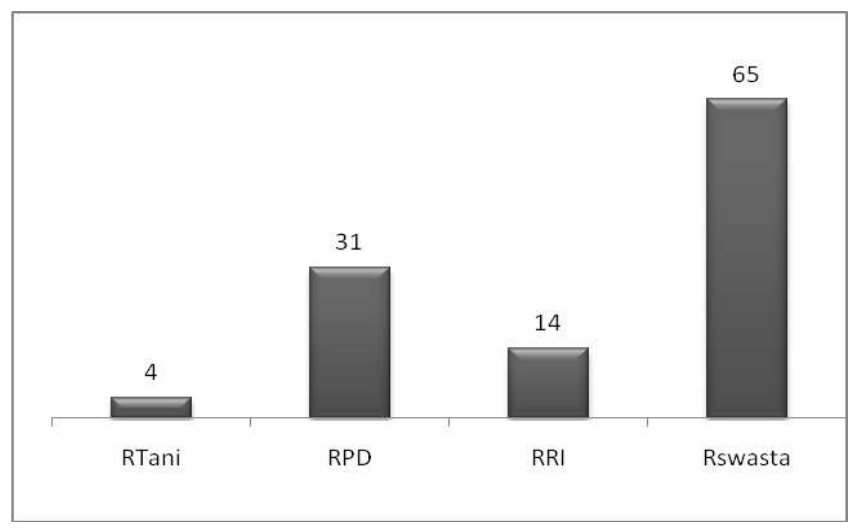

Gambar 3. Stasiun Radio yang diikuti Penyuluh

hiburan (Tabel 2). Media televisi juga memiliki karakteristik yang mampu menampilkan pesan audio visual dan unsur gerak yang identik dengan media hiburan dan informasi, sehingga wajar jika penyuluh 76 persen menonton televisi acara hiburan dan olahraga, 64 persen acara tentang ekonomi bisnis, 61 persen acara yang terkait dengan politik, 52 persen masalah pendidikan, dan 44 persen tentang pertanian. Begitu pula stasiun televisi yang sering ditonton penyuluh (Gambar 4) lebih banyak menyajikan acara yang sifatnya hiburan.

Gambar 4 menunjukkan stasiun televisi yang sering ditonton penyuluh menyiarkan acara yang bersifat umum. Intensitas pemanfaatan media televisi sudah tinggi, tetapi substansinya kurang sesuai dengan kegiatan penyuluhan. Di Indonesia belum ada stasiun televisi yang menyiarkan secara khusus tentang pertanian. Acara-acara

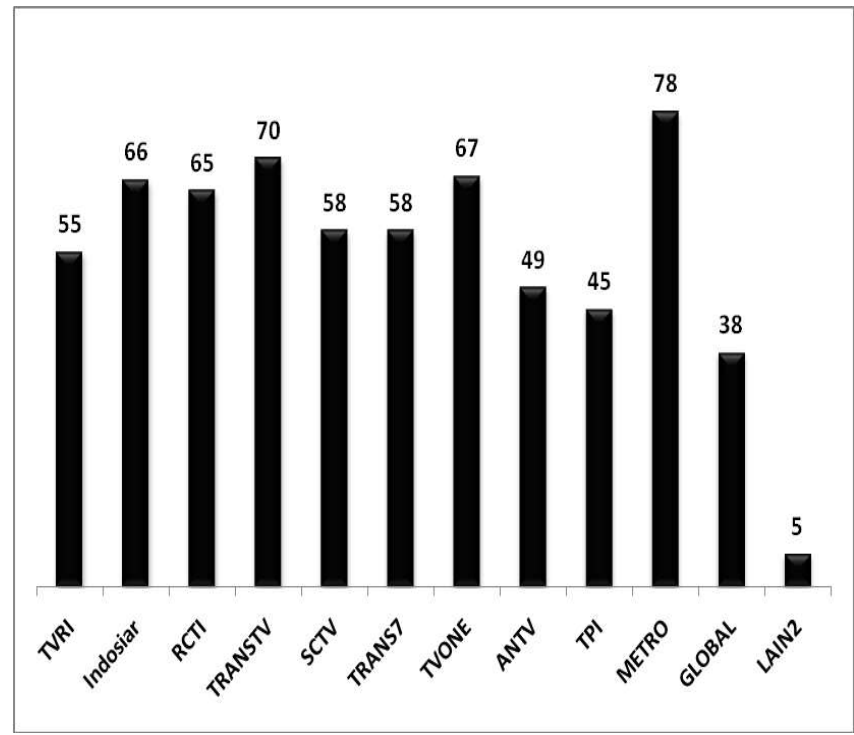

Gambar 4. Stasiun Televisi yang sering diikuti Penyuluh televisi yang bernuasa pertanian masih dilakukan secara insidental, sehingga sasaran seperti penyuluh belum bisa optimal memanfaatkan siaran tersebut. Ini adalah tantangan dan sekaligus peluang bagaimana menyediakan substansi yang terkait dengan penyuluhan melalui media televisi, atau membangun channel khusus televisi yang bisa menyiarkan substansi pertanian secara penuh dan kontinyu, seperti yang telah dilakukan oleh pemerintah China (Pustekkom, 2006). Kemajuan pertelevisian dari teknologi analog ke teknologi digital dimungkinkan untuk membuka saluran khusus siaran pertanian.

Intensitas pemanfaatan media internet di lingkungan penyuluh sangat rendah. Terbukti secara umum rataan skor hanya 8 , bahkan 82 persen penyuluh menyatakan belum pernah mengakses media ini (Tabel 1). Artinya, hanya 12 persen penyuluh yang sudah pernah mengakses internet dengan intensitas yang sangat rendah. Rendahnya intensitas pemanfaatan media ini terkait dengan keterbatasan sarana dan prasarana untuk mengakses internet, termasuk di kantor Balai Penyuluhan Pertanian (BPP) atau UPTD Pertanian belum tersedia internet. Begitu pula jenis informasi (Tabel 2) yang sering diakses penyuluh adalah informasi hiburan.

Secara teoritis internet memiliki potensi besar sebagai media komunikasi dan informasi untuk memenuhi tuntutan perubahan dalam penyuluhan. Potensi ini bisa direalisasikan apabila lembaga penyuluhan atau pemerintah (pusat dan daerah) menyediakan kemudahan akses internet bagi penyuluh. Upaya ini penting dilakukan guna menciptakan kebutuhan informasi dan komunikasi kepada penyuluh melalui teknologi internet. Menurut Littlejohn (1996), kebutuhan merupakan sesuatu yang datang dalam diri, akan tetapi bisa saja diciptakan atau ditajamkan oleh budaya masyarakat sekitar atau kondisi sosial tertentu yang berada di luar kontrol individu. Terobosan pemerintah melalui Departemen Komunikasi dan Informasi dalam merealisasikan menuju "Desa Pintar" yang mana setiap desa bisa mengakses internet, merupakan bukti membangun budaya pentingnya informasi dan komunikasi di masyarakat (pedesaan). Dalam lingkungan penyuluhan, upaya menciptakan kebutuhan informasi melalui internet perlu dibudayakan. 
Hasil uji regresi dengan diketahui bahwa variabel yang menunjukkan pengaruh langsung dan nyata terhadap kompetensi penyuluh hanya intensitas pemanfaatan majalah, seperti disajikan dalam Tabel 3.

Tabel 3. Media Massa yang Mempengaruhi Kompetensi Penyuluh

\begin{tabular}{|l|c|c|}
\hline $\begin{array}{l}\text { Intensitas } \\
\text { Peman- } \\
\text { faatan }\end{array}$ & $\begin{array}{c}\text { Koefisien } \\
\text { yang telah } \\
\text { distandari- } \\
\text { sasi }\end{array}$ & $\begin{array}{c}\text { Nilai } \\
\text { signifikan }\end{array}$ \\
\hline Koran & 0,107 & 0,179 \\
\hline Majalah & 0,356 & 0,000 \\
\hline Buku & 0,062 & 0,410 \\
\hline Radio & $-0,012$ & 0,872 \\
\hline Televisi & 0,059 & 0,439 \\
\hline Internet & 0,059 & 0,473 \\
\hline
\end{tabular}

Adanya pengaruh yang nyata antara intensitas pemanfaatan majalah dengan kompetensi penyuluh, menunjukkan bahwa makin tinggi pemanfaatan majalah maka kompetensinya meningkat. Sebaliknya media massa lain yang diuji dalam penelitian ini yaitu koran, buku, radio, televisi, dan internet tidak berpengaruh nyata. Hasil pendalaman diketahui bahwa majalah yang sering dibaca penyuluh (Gambar 2) adalah Majalah Sinar Tani dan Trubus.

Majalah Sinar Tani dan Trubus adalah majalah yang substansinya secara spesifik merupakan majalah pertanian, sedangkan majalah Tempo dan Gatra substansinya lebih bersifat umum. Majalah Sinar Tani awalnya diterbitkan oleh Departemen Pertanian sebulan dua kali dan didistribusikan kepada seluruh penyuluh PNS di Indonesia dengan pembiayaan dipotong dari penghasilan mereka. Topik-topik aktual yang terkait dengan pertanian menjadi bahasan utama majalah Sinar Tani. Majalah ini juga menyajikan inovasi atau teknologi baru, kajian permasalahan pertanian, sharing pengalaman, dan juga sebagai media komunikasi.

Hasil pendalaman juga diketahui bahwa melalui majalah ini informasi yang sering dibaca penyuluh (Tabel 2) sebagian besar adalah informasi yang terkait dengan penyuluhan pertanian. Uraian data pendukung tersebut menunjukkan bahwa karakteristik majalah yang sering dibaca penyuluh adalah (1) majalah yang spesifik tentang pertanian, (2) substansi yang diperoleh juga terkait dengan pertanian dan keperluan kegiatan penyuluhan, serta (3) majalah tersebut (khususnya Sinar Tani) diperoleh secara kontinyu (dua kali dalam sebulan).

Hasil ini sesuai dengan pendapat Straubhaar dan LaRose (2002), bahwa media massa terkait dengan pembelajaran, setelah individu mengkonsumsi suatu media, individu tersebut akan berpikir, bersikap, dan melakukan suatu tindakan, yang diakibatkan oleh pengaruh media tersebut. Bila media itu memberikan pengaruh positif kepada dirinya, maka akan mengulang untuk mengkonsumsi media yang memiliki karakteristik yang sama. Demikian pula sebaliknya, apabila mendapatkan hal yang negatif maka ia akan menolak media yang memiliki karakteristik seperti itu. Majalah Sinar Tani memberikan pengaruh positif terhadap penyuluh, terutama memberikan wawasan dan pemahaman yang terkait dengan materi penyuluhan.

Dengan karakteristik seperti itu, media massa ini ternyata tidak hanya berpengaruh dalam tataran kesadaran atau menggugah minat, akan tetapi mampu mempengaruhi secara nyata dan positif dalam meningkatkan kompetensi penyuluh, sebagai komunitas terdidik. Dengan kata lain, media massa (majalah) pada sasaran yang memiliki tingkat pendidikan relatif baik (Tichenor, dalam Severin dan Tankard, 2001), substansinya sesuai kebutuhan sasaran, dan dilakukan secara berkelanjutan dapat mempengaruhi kompetensinya, dalam hal ini penyuluh.

Media massa selain Majalah (Tabel 2) menunjukkan bahwa informasi yang diperoleh penyuluh sebagian besar bersifat hiburan dan informasi umum lainnya. Sebagai media massa yang menyajikan beragam informasi, penyuluh dapat menyeleksi jenis media dan informasi yang tepat sesuai dengan kebutuhan. Hal ini sesuai dengan teori Uses and Gratifications yang menekankan bahwa masyarakat (penyuluh) memiliki kekuasaan untuk memilih media massa yang sesuai dengan kebutuhan dirinya. Pemilihan media massa yang tepat bisa dilakukan apabila ada alternatif pilihan media massa dan kemudahan untuk mengaksesnya. Dalam Tabel 2 diketahui hanya majalah yang substansinya relevan dengan penyuluhan, sedangkan media lainnya masih 
kurang. Ini berarti pemilihan media massa oleh penyuluh yang sesuai dengan kebutuhan penyuluhan masih sulit dilakukan.

Pemanfaatan koran tidak berpengaruh secara nyata terhadap kompetensi. Hal ini disebabkan karena: (1) informasi/substansi koran kurang sesuai dengan penyuluhan (Tabel 2), masih belum ada koran (harian) yang secara khusus membahas tentang pertanian seperti halnya majalah Sinar Tani, (2) penyuluh yang umumnya tinggal di pedesaan/kota kecamatan sulit dijangkau dengan koran harian, dan (3) intensitas pemanfaatan koran sangat rendah (Tabel 1).

Intensitas pemanfaatan buku menunjukkan tidak berpengaruh nyata terhadap kompetensi penyuluh, padahal jika diperhatikan substansi buku yang dibaca penyuluh sesuai dengan penyuluhan. Hal ini dipengaruhi oleh tingkat pemanfaatanya sangat rendah (Tabel 1 ). Di sisi lain tingkat ketertarikan membaca buku lebih rendah dibandingkan dengan membaca koran. Kondisi ini juga terkait dengan masih lemahnya budaya membaca bangsa kita termasuk kaum terdidik (penyuluh). Menurut Badan Pusat Statistik (BPS) pada tahun 2003 bahwa penduduk Indonesia berumur di atas 15 tahun yang membaca koran hanya 55,11 persen, sedangkan membaca majalah atau tabloid hanya 29,22 persen, buku cerita 16,72 persen, buku pelajaran sekolah 44.28 persen, dan yang membaca buku ilmu pengetahuan lainnya hanya 21,07 persen. Data BPS lainnya juga menunjukkan bahwa penduduk Indonesia belum menjadikan membaca sebagai kebutuhan informasi. Orang lebih memilih televisi dan mendengarkan radio. Malahan, kerelatifan cara mendapatkan informasi lewat membaca stagnan sejak 1993. Hanya naik sekitar 0,2 persen. Jauh jika dibandingkan dengan menonton televisi yang kenaikan persentasenya mencapai 211 persen. Data BPS (2006) menunjukkan bahwa orang Indonesia yang membaca untuk mendapatkan informasi baru 23,5 persen dari total penduduk, sedangkan menonton televisi sebanyak 85,9 persen dan mendengarkan radio sebesar 40,3 persen. Data tersebut menggambarkan bahwa minat baca penduduk Indonesia masih rendah.

Intensitas pemanfaatan media radio juga tidak berpengaruh terhadap kompetensi. Hal ini dapat dianalisis bahwa sebagian besar acara radio yang diikuti penyuluh (Tabel 2 ) bersifat hiburan, begitu pula data stasiun radio yang sering didengarkan penyuluh (Gambar 2) sebagian besar adalah radio swasta yang materi siarannya didominasi oleh unsur hiburan. Padahal radio memiliki karakteristik yang mudah dibawa dan dimanfaatkan termasuk bisa didengarkan sambil bekerja (lebih praktis) dibandingkan dengan media massa baik cetak maupun media elektronik lainnya. Ini adalah peluang untuk membangun radio pertanian dalam menunjang peningkatan kompetensi penyuluh.

Media televisi seperti halnya dalam masyarakat Indonesia merupakan media massa yang paling digemari masyarakat. Media televisi juga memiliki karakteristik yang mampu menampilkan pesan audio visual dan unsur gerak yang identik dengan media hiburan dan informasi. Kondisi ini juga terjadi pada penyuluh, bahwa intensitas pemanfaatan televisi sangat tinggi tetapi substansinya kurang sesuai dengan penyuluhan (Tabel 2), sehingga tidak berpengaruh nyata terhadap peningkatan kompetensi penyuluh. Jika media ini dimanfaatkan secara kontinyu dan substansi yang relevan dengan penyuluhan maka dapat ditafsirkan bahwa media televisi memiliki potensi untuk berpengaruh terhadap kompetensi penyuluh.

Di Indonesia belum ada stasiun televisi yang khusus menyiarkan acara yang ditunjukan untuk pertanian. Beberapa acara sudah ada kerja sama Departemen Pertanian dengan beberapa stasiun televisi, tetapi masih insidental. Padahal seperti di China (CCTV), melalui Channel 7 telah mampu memberikan pencerahan kepada para petani dan penyuluh di seluruh negeri China. Kemajuan teknologi analog ke digital, memberikan peluang lebih besar dalam pemanfaatan siaran televisi melalui saluran yang mengkhususkan untuk pertanian.

Berbeda dengan televisi, internet merupakan media yang paling sedikit dimanfaatkan penyuluh. Hanya tiga persen penyuluh yang sudah memiliki internet pribadi. Dalam pemanfaatannya, 14 persen mengakses untuk hiburan, tujuh persen mencari informasi bidang ekonomi dan bisnis, tiga persen mencari informasi pertanian, dan tiga persen untuk keperluan lainnya seperti kirim email. Begitupun rataan skor pemanfaatan media ini sangat rendah (Tabel 1 ). Itulah sebabnya 
intensitas pemanfaatan media internet ini tidak berpengaruh nyata terhadap peningkatan kompetensinya. Hasil penelitian Awang (2002) di Malaysia, menunjukkan bahwa penggunaan internet lebih banyak dilakukan oleh kaum muda dan kaum yang berpendidikan tinggi. Penelitian Rahardjo (2001) menunjukkan bahwa salah satu kesulitan dalam pemanfaatan internet adalah biaya untuk mengakses masih relatif mahal. Penyuluh PNS yang umurnya sudah mendekati usia pensiun (tua) dan kesulitan akses internet (relatif mahal) menjadi penyebab sangat rendahnya intensitas pemanfaatan media ini.

\section{Simpulan dan Saran Simpulan}

Secara umum intensitas pemanfaatan media massa (koran, majalah/tabloid, buku, radio, televisi, dan internet) dalam meningkatkan kompetensi penyuluh rendah. Secara khusus intensitas pemanfaatan media seperti koran, buku, radio, dan internet dalam kategori sangat rendah. Pemanfaatan majalah dalam kategori sedang dan hanya intensitas pemanfaatan media televisi dalam kategori tinggi.

Substansi informasi dari media massa yang diakses penyuluh secara umum kurang sesuai dengan kebutuhan penyuluhan. Informasi media massa didominasi oleh unsur hiburan dan informasi yang bersifat umum. Substansi media massa yang sesuai dengan kebutuhan penyuluh pertanian hanya majalah.

Media massa (koran, majalah/tabloid, buku, radio, televisi, dan internet) yang berpengaruh terhadap kompetensi penyuluh pertanian adalah majalah. Majalah ini memiliki karakteristik substansinya sesuai dengan kebutuhan penyuluhan, mudah diakses penyuluh, dan dilakukan secara kontinyu.

\section{Pustaka Acuan}

Awang, Hizamnuddin. 2002 Teknografi Pengguna Internet. http://www. magazin. jaringan.my/2000/ november/index2.html?content=stay12.html (4 Nov.2002)

Badan Pusat Statistik (BPS) Republik Indonesia. 2003. Persentase Penduduk Berumur 15 Tahun ke Atas yang Menonton Televisi, Mendengarkan Radio, dan Membaca Surat Kabar/ Majalah/Buku. http://www.bps.go.id/tab sub/view.php?tabel $=1 \&$ daftar $=1 \& i d$ subyek $=27 \&$ notab $=25$ (5 Februari 2010).

Badan Pusat Statistik (BPS) Republik Indonesia. 2006. Persentase Penduduk Berumur 15 Tahun ke Atas yang Menonton Televisi, Mendengarkan Radio, dan Membaca Surat Kabar/ Majalah/Buku.

\section{Saran}

Kesadaran penyuluh perlu ditingkatkan untuk terus belajar dalam meningkatkan kompetensinya sesuai tuntutan masyarakat. Belajar adalah tuntutan profesi bagi penyuluh pertanian. Belajar ini tidak hanya melalui pendidikan formal atau pelatihan saja, melainkan media lainnya banyak yang dapat dimanfaatkan untuk meningkatkan kemampuan penyuluh, terutama media massa yang mudah diakses dan substansinya sesuai dengan kebutuhan penyuluhan.

Pemerintah baik pemerintah pusat maupun daerah perlu memiliki komitmen yang kuat untuk memanfaatkan media massa sebagai salah satu alternatif dalam meningkatkan kemampuan penyuluh pertanian yang tersebar di berbagai pelosok tanah air, sebagai bekal/amunisi bagi mereka untuk melaksanakan penyuluhan yang bermutu. Begitu pula para pengelola media massa dan pihak-pihak lainnya dituntut memiliki kepedulian untuk menyajikan substansi media massa yang terkait dengan penyuluhan dan pertanian di pedesaan.

Temuan lain dari penelitian ini adalah tingginya potensi media televisi sebagai media yang dapat digunakan untuk peningkatan kompetensi penyuluh. Oleh karena itu, pengembangan kompetensi penyuluh pertanian berbasis pemanfaatan media massa dapat dilakukan melalui media cetak (majalah) dan media elektronik (televisi) dengan substansi yang sesuai kebutuhan penyuluhan, mudah diakses oleh penyuluh, dan dilakukan secara kontinyu. Perlu juga dilakukan penelitian lebih lanjut secara spesifik tentang substansi informasi, format sajian, dan sistem pengelolaan dalam pemanfaatan media massa guna meningkatkan kompetensi penyuluh yang berada di pedesaan seluruh pelosok tanah air. 
http://www.bps.go.id/tab sub/view.php?tabel=1\&daftar=1\&id subyek $=27 \&$ notab $=35$ (12 Februari 2010).

Boyatzis, RE. 1984. The Competent Manager: A Model for Effective Performance. New York: Jihn Willy \& Sons.

Kincaid, D. Lawrence dan Wilbur Schramm. 1987. Asas-Asas Komunikasi Antar Manusia. Edisi Indonesia. Jakarta: LP3ES.

Littlejohn, SW. 1996. Theories of Human Communication. Wadsworth, Publishing Company. An International Thomson Publishing Company.

Nasution, Zulkarimein. 2007. Komunikasi Pembangunan: Pengenalan Teori dan Penerapanya. Jakarta: Rajawali Press.

Oepen, Manfred. 1988. Development Support Communication in Indonesia. Edisi Indonesia: Media Rakyat: Komunikasi Pembangunan Masyarakat. P3M Jakarta.

Pustekkom, Depdiknas. 2006. Laporan Studi Banding Pemanfaatan Media Televisi untuk Pendidikan di China. Jakarta: Pustekkom Depdiknas.

Rahardjo, Budi. 2001. Pergolakan Informasi di Indonesia akan Sia-sia?. Artikel Majalah Tempo. Jakarta: November 2001.

Sendjaja, Sasa Djuarsa, dan Ilya Sumawinardi. 1994. Teori Komunikasi; Materi Pokok Modul Universitas Terbuka, Jakarta: UT.

Sevilla, C. G., J. A. Ochave, T. G. Punsalan, B. P. Regala, dan G. G. Uriarte. 1993. Pengantar Metode Penelitian. Jakarta: Universitas Indonesia Press.

Severin, J. Werner dan James W. Tankard. 2001. Communication Theory: Origin, Methods, and Uses in The Mass Media. Eddison Wesley Lngman, Inc.

Slamet, Margono. 2008."Menuju Pembangunan Berkelanjutan melalui Implementasi UU No. 16 tahun 2006 tentang Sistem Penyuluhan Pertanian, Perikanan, dan Kehutanan." Dalam Pemberdayaan Manusia Pembangunan yang Bermartabat. Penyunting: Adjat Sudrajat dan Ida Yustina. Bogor: Sydex Plus.

Spencer, M. Lyle dan M. Signe Spencer. 1993. Competence at Work: Models for Superrior Performance, John Wily \& Son, Inc. New York, USA.

Sumardjo, 2008. "Penyuluhan Pembangunan: Pilar Pendukung Kemajuan dan Kemandirian Masyarakat." Dalam Pemberdayaan Manusia Pembangunan yang Bermartabat. Penyunting: Adjat Sudrajat dan Ida Yustina. Bogor: Sydex Plus.

Straubhaar, Joseph dan Rober LaRose. 2002. Media Now: Communications Media in the Informatyion Age. Third Edition. Belmon. CA: Wadsworth.

Wiryanto, 2000. Teori Komunikasi Massa. Jakarta: Grasindo 